\title{
Germline transformation of Aedes fluviatilis (Diptera:Culicidae) with the piggyBac transposable element
}

\author{
Flávia Guimarães Rodrigues, Sabrina Barbosa Oliveira, Bruno Coelho Rocha, \\ Luciano Andrade Moreira ${ }^{+}$
}

\author{
Laboratório de Malária, Centro de Pesquisas René Rachou-Fiocruz, Av. Augusto de Lima 1715, 30190-002 \\ Belo Horizonte, MG, Brasil
}

\begin{abstract}
The technique to generate transgenic mosquitoes requires adaptation for each target species because of aspects related to species biology, sensitivity to manipulation and rearing conditions. Here we tested different parameters on the microinjection procedure in order to obtain a transgenic Neotropical mosquito species. By using a transposonbased strategy we were able to successfully transform Aedes fluviatilis (Lutz), which can be used as an avian malaria model. These results demonstrate the usefulness of the piggyBac transposable element as a transformation vector for Neotropical mosquito species and opens up new research frontiers for South American mosquito vectors.
\end{abstract}

Key words: transgenic mosquitoes - piggyBac - malaria

The insertion of foreign genes into the genome of an organism is an important tool to address the expression of a particular gene, to study parasite-vector interactions and also for practical uses. The first stable transformation of a mosquito was achieved by Coates et al. (1998) and by Jasinskiene et al. (1998) who expressed a species-specific eye colour gene, in Aedes aegypti (Linnaeus). A great achievement was obtained with the use of the green fluorescent protein (GFP), as a selective marker, because it has the advantage to express in a variety of species, including insects (Pinkerton et al. 2000, Horn \& Wimmer 2000, Catteruccia et al. 2000, Kokoza et al. 2001), and on early developmental stages. Furthermore, with the discovery that the transposon piggyBac was able to work in different organisms [insects (Handler \& Harrell 1999, Handler \& MacCombs 2000, Grossman et al. 2001, Peloquin et al. 2000, Tamura et al. 2000, Ito et al. 2002, Moreira et al. 2002, Kim et al. 2004, Franz et al. 2006) and even in mouse (Ding et al. 2005), planaria (Gonzalez-Estevez et al. 2003), and Plasmodium falciparum (Balu et al. 2005)], a wide horizon has opened on the transformation of insects of both agricultural and medical/veterinary importance.

Although several mosquito species have been transformed so far, there are differences related to each species and consequently, adaptation of the transformation technique is required.

Aedes fluviatilis (Lutz) is a zoophilic and anthropophilic species, with a geographical distribution comprehending the Southern part of Mexico to the Northern part of Argentina, east of Andes. This species has being used

Financial support: TDR/WHO (grant A20741)

FG Rodrigues, BC Rocha, and LA Moreira: CNPq research scholarships; SB Oliveira: Fapemig research scholarship

${ }^{+}$Corresponding author: luciano@cpqrr.fiocruz.br

Received 25 July 2006

Accepted 28 August 2006 in laboratory as a safe avian malaria vector (Tason de Camargo \& Krettli 1978), as it does not naturally transmit dengue or yellow fever.

Here we report the first successful stable transformation of Ae. fluviatilis, by using the piggyBac transposable element, being the first report of genetically manipulation of mosquitoes in Latin America.

\section{MATERIALS AND METHODS}

Ae. fluviatilis mosquitoes were reared at $27^{\circ} \mathrm{C}$ and $80 \%$ humidity under a $12 \mathrm{~h}$ light/dark cycle. For adults, $10 \%$ sucrose solution was offered ad libitum and females were fed on mouse blood. Larvae were fed on fish food (Goldfish Colour, Alcon).

The transformation plasmids [piggyBac 3xP3-EGFP (Horn \& Wimmer 2000) and phsp-Helper plasmid] were purified by using a Plasmid Maxi-Prep kit (Qiagen). Plasmids were mixed to a final concentration of $0.3 \mu \mathrm{g} / \mu \mathrm{l}$ (piggyBac) and $0.2 \mu \mathrm{g} / \mu \mathrm{l}$ (Helper plasmid) in injection buffer $\left(5 \mathrm{mM} \mathrm{KCl}, 0.1 \mathrm{mM} \mathrm{Na}_{2} \mathrm{HPO}_{4}, \mathrm{pH} 6.8\right)$ plus $5 \%$ (vol/ vol) of green food colour to help visualization of injection mixture.

Three days old females were fed on mouse blood and two days after, eggs were collected by forced egg laying. Thirty to 45 min embryos were lined up with their posterior ends towards the same side onto a square of filter paper soaked with isotonic buffer $(150 \mathrm{mM} \mathrm{NaCl}, 5 \mathrm{mM}$ $\mathrm{KCl}, 10 \mathrm{mM} \mathrm{HEPES}, 2.5 \mathrm{mM} \mathrm{CaCl}_{2}, \mathrm{pH} 7.2$ ), the filter paper was dried-up and the embryos were transferred to a glass slide containing double-sided tape and covered with halocarbon oil 27 (Sigma-Aldrich).

Microinjections were performed by using a Femtojet injector (Eppendorf) and an inverted microscope (TS100, Nikon) attached to a micromanipulator (Narishige). Microinjection parameters were: $600 \mathrm{hPa}$ (injection pressure); $100 \mathrm{hPa}$ (back pressure) and manual control of injection time. Quartz capillaries were pulled on a laser-based puller (Sutter) using the following pulling parameters: Heat $=$ 750, Fil $=4$, Vel $=40$, Del $=125$, Pull $=125$ and the tip was broken by touching the first embryo to be injected.

Surviving injected larvae were maintained in filtered 
tap water until adulthood. Injected males were mated with colony-originated females and injected females with colony counterparts forming injected G0 families. Four egg batches were collected from each family and the larvae screened on a FITC-fluorescence microscope (Nikon TS-100F). Transgenic lines expressing the EGFP marker were crossed with colony insects for expansion. EGFP specific oligonucleotides (EGFPfor: 5'-ggtgcccatcctgg tcgagc-3' and EGFPrev: 5'-gcggtcacgaactccagcagg- 3') were used to identify the presence of the transgene with the following polymerase chain reaction (PCR) $\left(95^{\circ} \mathrm{C} 2\right.$ min, 30 cycles of $95^{\circ} \mathrm{C} 1 \mathrm{~min}, 63^{\circ} \mathrm{C} 1 \mathrm{~min}$ and $72^{\circ} \mathrm{C} 1 \mathrm{~min}$, followed by $72^{\circ} \mathrm{C}, 5 \mathrm{~min}$ ).

\section{RESULTS AND DISCUSSION}

In order to adapt the microinjection technique, which has been used to other Culicidae species we tested different parameters to obtain the best larval hatching after the microinjection procedure and consequently, to increase the chances of transformation. First, we have tested the possibility of maintaining the embryos on ice to reduce embryo aging and consequently to expand the injection time, but that procedure drastically reduced larval hatching even in control embryos, which were not injected (data not shown). We tested post-injection manipulations of mosquito embryos, in order to obtain higher larval hatching. We compared the transference of embryos to a damp filter paper with the use of a fine paintbrush prior to transfer the eggs to water or by dipping the slide containing eggs in $\mathrm{ddH}_{2} \mathrm{O}$ three times, to remove oil excess. The highest larval hatching was obtained when the slide containing eggs was dipped in water to remove oil excess and the embryos were transferred to a Petri dish filled with water and with filter paper on its border.

With the 84 adults that survived microinjection, $15 \mathrm{G} 0$ families were formed and after screening of more than 17,000 larvae (G1), four transgenic lines were obtained (Table), resulting in a transformation frequency of $27 \%$, based on G0 families. Fig. 1A shows the typical phenotypic characteristic of transformed mosquitoes with the use of 3xP3 promoter (Horn \& Wimmer 2000) when driving the expression of EGFP. Larval, pupal and adult eyes, larval neural tube and larvae anal papillae exhibits a strong green fluorescence [similar to previously shown for $A e$. aegypti (Kokoza et al. 2001) and for Anopheles stephensi (Liston) (Ito et al. 2002)], which is detectable even on first instar larvae. The presence of the EGFP gene in transgenic larvae is shown on Fig. 1B, by PCR, in comparison to nontransformed individuals.

This work shows the functionality of the piggyBac transposable element, as a transformation vector, in another mosquito species. Our findings open new possibilities to genetic manipulate South American mosquito species to better understand their interaction with parasites they transmit, in our particular conditions. Work is in progress in adapting this technology to transform a Brazilian malaria vector, Anopheles aquasalis (Curry), which shall express a Plasmodium-blocking molecule.
A

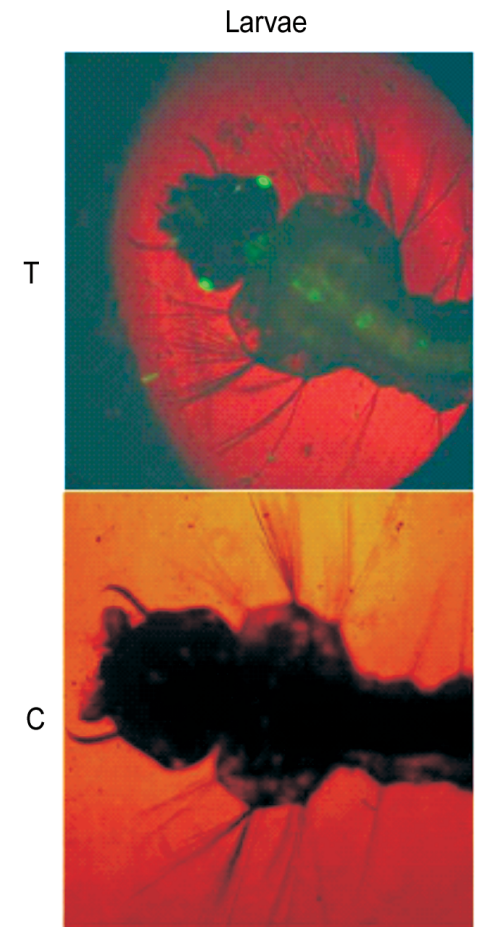

B

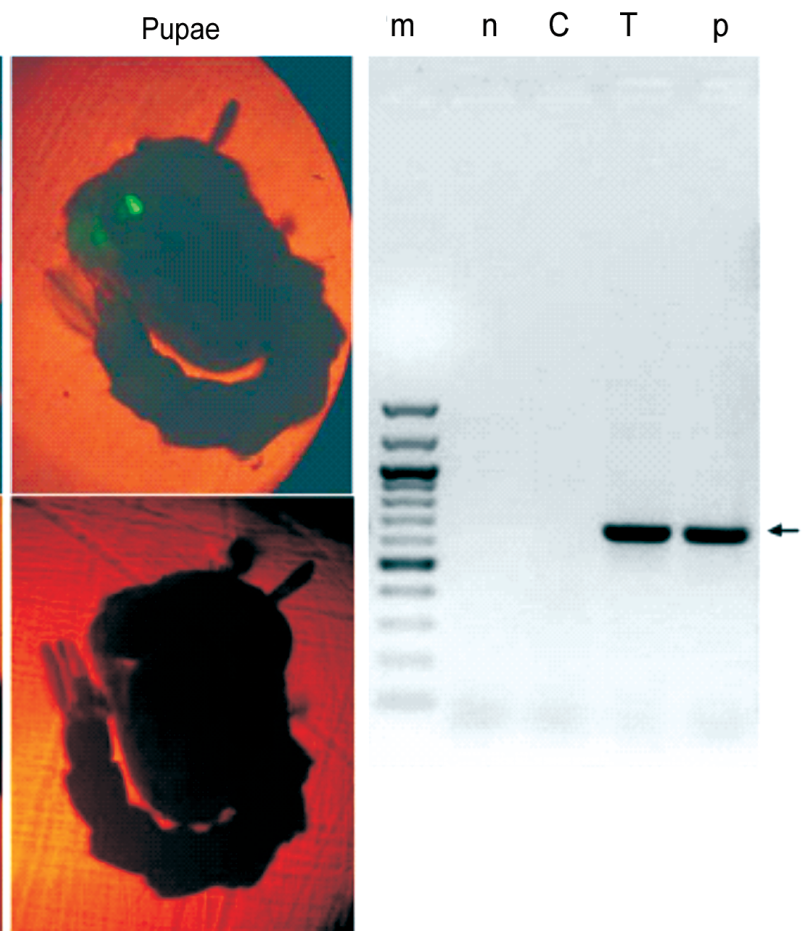

Fig. 1: expression of the enhanced green fluorescent protein (EGFP) gene in transgenic Aedes fluviatilis. A: larvae and pupae of both transgenic $(\mathrm{T})$ and non-transgenic mosquitoes (C); B: ethidium bromide stained 1\% agarose gel, showing the amplification of the EGFP gene, by polymerase chain reaction, with EGFP specific primers; m: DNA marker (New England Biolabs 100 pb); n: no DNA added; C: nontransgenic larvae; T: transgenic larvae; p: piggyBac 3xP3/EGFP DNA. 
TABLE

Number of injected embryos, surviving adults, number of transgenic families and transformation frequency in Aedes fluviatilis

\begin{tabular}{lcccccc}
\hline Experiment $^{a}$ & $\begin{array}{c}\text { Embryos } \\
(\mathrm{n})\end{array}$ & $\begin{array}{c}\text { Larvae } \\
(\% \text { hatch) }\end{array}$ & $\begin{array}{c}\text { Surviving } \\
\text { adults }\end{array}$ & $\begin{array}{c}\text { Fertile } \\
\text { families }\end{array}$ & $\begin{array}{c}\text { Transgenic (GFP) } \\
\text { families }\end{array}$ & $\begin{array}{c}\text { Transformation } \\
\text { frequency }\end{array}$ \\
\hline Control 1 & 254 & $140(100)$ & $\mathrm{n} / \mathrm{d}$ & $\mathrm{n} / \mathrm{d}$ & - & - \\
Control 2 & 236 & $83(64)$ & $\mathrm{n} / \mathrm{d}$ & $\mathrm{n} / \mathrm{d}$ & - & - \\
Injected & 770 & $108(25)$ & 84 & 15 & 4 & $27 \%$ \\
\hline
\end{tabular}

$a$ : control 1 are embryos that were collected and directly placed in water for hatching. Control 2 were embryos submitted to all procedures before injection (see text), but not injected; $b$ : for larval hatching calculation, Control 1 embryos were considered as $100 \%$ hatching; $c$ : transformation frequency was calculated based on fertile families; $\mathrm{n} / \mathrm{d}$ : numbers not determined.

\section{ACKNOWLEDGEMENTS}

To Dr Marcelo Jacobs-Lorena, who kindly provided us the transformation plasmids. To Maira S Neves and Geraldo F Carvalho for their great technical support and Cristiana FA Brito for critical reading.

\section{REFERENCES}

Balu B, Shoue DA, Fraser Jr MJ, Adams JH 2005. High-efficiency transformation of Plasmodium falciparum by the lepidopteran transposable element piggyBac. Proc Natl Acad Sci USA 102: 16391-16396.

Catteruccia F, Nolan T, Loukeris TG, Blass C, Savakis C, Kafatos FC, Crisanti A 2000. Stable germline transformation of the malaria mosquito Anopheles stephensi. Nature 405: 959962.

Coates CJ, Jasinskiene N, Miyashiro L, James AA 1998. Mariner transposition and transformation of the yellow fever mosquito, Aedes aegypti. Proc Natl Acad Sci USA 95: 37483751 .

Ding S, Wu X, Li G, Han M, Zhuang Y, Xu T 2005. Efficient transposition of the piggyBac (PB) transposon in mammalian cells and mice. Cell 12: 473-483.

Franz AWE, Sanchez-Vargas I, Adelman ZN, Blair CD, Beaty BJ, James AA, Olson KE 2006. Engineering RNA interference-based resistance to dengue virus type 2 in genetically modified Aedes aegypti. Proc Natl Acad Sci USA 103: 41984203.

Gonzalez-Estevez C, Momose T, Gehring WJ, Salo E 2003. Transgenic planarian lines obtained by electroporation using transposon-derived vectors and an eye-specific GFP marker. Proc Natl Acad Sci USA 100: 14046-14051.

Grossman GL, Rafferty CS, Clayton JR, Stevens TK, Mukabayire O, Benedict MQ 2001. Germline transformation of the malaria vector, Anopheles gambiae, with the piggyBac transposable element. Insect Mol Biol 10: 597-604.

Handler AM, Harrell RA 1999. Germline transformation of Drosophila melanogaster with the piggyBac transposon vector. Insect Mol Biol 8: 449-457.

Handler AM, McCombs SD 2000. The piggyBac transposon mediates germ-line transformation in the Oriental fruit fly and closely related elements exist in its genome. Insect Mol Biol 9: 605-612.
Horn C, Wimmer EA 2000. A versatile vector set for animal transgenesis. Dev Genes Evol 210: 630-637.

Ito J, Ghosh A, Moreira, LA, Wimmer EA, Jacobs-Lorena M 2002. Transgenic anopheline mosquitoes impaired in transmission of a malaria parasite. Nature 417: 452-455.

Jasinskiene N, Coates CJ, Benedict MQ, Cornel AJ, Rafferty CS, James AA, Collins FH 1998. Stable transformation of the yellow fever mosquito, Aedes aegypti, with the Hermes element from the housefly. Proc Natl Acad Sci USA 95: 3743-3747.

Kim W, Koo H, Richman AM, Seeley D, Vizioli J, Klocko AD, O'Brochta DA 2004. Ectopic expression of a cecropin transgene in the human malaria vector mosquito Anopheles gambiae (Diptera: Culicidae): effects on susceptibility to Plasmodium. J Med Entomol 41: 447-455.

Kokoza V, Ahmed A, Wimmer EA, Raikhel AS 2001. Efficient transformation of the yellow fever mosquito Aedes aegypti using the piggyBac transposable element vector pBac [3xP3EGFP afm]. Insect Biochem Mol Biol 31: 1137-1143.

Moreira LA, Ito J, Ghosh A, Devenport M, Zieler H, Abraham EG, Crisanti A, Nolan T, Catteruccia F, Jacobs-Lorena M 2002. Bee venom phospholipase inhibits malaria parasite development in transgenic mosquitoes. J Biol Chem 277: 40839-40843.

Peloquin JJ, Thibault ST, Staten R, Miller TA 2000. Germ-line transformation of pink bollworm (Lepidoptera: Gelechiidae) mediated by the piggyBac transposable element. Insect Mol Biol 9: 323-333.

Pinkerton AC, Michel K, O’Brochta DA, Atkinson PW 2000. Green fluorescent protein as a genetic marker in transgenic Aedes aegypti. Insect Mol Biol 9: 1-10.

Tamura T, Thibert C, Royer C, Kanda T, Abraham E, Kamba M, Komoto N, Thomas JL, Mauchamp B, Chavancy G, Shirk P, Fraser M, Prudhomme JC, Couble P, 2000. Germline transformation of the silkworm Bombyx mori L. using a piggyBac transposon-derived vector. Nat Biotechnol 18: 8184 .

Tason de Camargo M, Krettli AU 1978. Aedes fluviatilis (Lutz), a new experimental host for Plasmodium gallinaceum Brumpt. J Parasitol 64: 924-925. 